\title{
EDUCORETAX
}

Volume 1 No. 4, Desember 2021

\section{PENGGUNAAN INFORMASI HARTA PADA PEMILIHAN WAJIB PAJAK YANG AKAN DIPERIKSA}

\author{
Habib Asfiya Jauhari' ${ }^{1)}$; Fadlil Usman²) \\ 1) habibasfiya99@gmail.com, Politeknik Keuangan Negara STAN \\ 2) fadlil.81@pknstan.ac.id, Politeknik Keuangan Negara STAN* \\ *email korespondensi
}

\begin{abstract}
Taxes have an important role in the development of the country, especially in supporting development financing. Based on the self-assessment system, taxpayers are given full trust to calculate, pay and report their own tax obligations. In order for the process and implementation of the system to remain within the rules, several efforts have been made, one of which is law enforcement through the implementation of Tax Audit. With the existence of the Tax Audit, it is expected to increase compliance with the fulfillment of Taxpayer's tax obligations. This study discusses the use of property information in the selection of taxpayers to be examined in a special examination with computerized risk analysis. This study uses a qualitative method. So far, the value of assets is not used in determining potential taxpayers to be audited because there is already quite a lot of existing data into consideration. Based on the results of the study, it is known that property information can be used in the selection of taxpayers to be audited. The value of the Taxpayer's assets shows the fiscal importance of each Taxpayer.
\end{abstract}

Keywords : Taxation, Tax Audit, Tax Data, Assets

\begin{abstract}
Abstrak
Pajak punya peran penting dalam pembangunan negara terutama dalam mendukung pembiayaan pembangunan. Berdasarkan sistem self assessment, Wajib Pajak diberi kepercayaan penuh untuk menghitung, membayar dan melaporkan sendiri kewajiban perpajakannya. Agar proses dan pelaksanaan sistem tersebut tetap berada pada aturannya dilakukan beberapa upaya yang salah satunya adalah dengan penegakan hukum melalui pelaksanaan Pemeriksaan Pajak. Dengan adanya Pemeriksan Pajak diharapkan dapat meningkatkan kepatuhan pemenuhan kewajiban perpajakan Wajib Pajak. Penelitian ini membahas penggunaan informasi harta pada pemilihan wajib pajak yang akan diperiksa dalam pemeriksaan khusus dengan analisis risiko terkomputerisasi. Penelitian ini menggunakan metode kualitatif. Selama ini nilai harta tidak digunakan dalam penentuan Wajib Pajak potensial untuk diperiksa karena sudah cukup banyak data-data yang ada yang menjadi pertimbangan. Berdasarkan hasil penelitian diketahui bahwa informasi harta bisa digunakan dalam pemilihan wajib pajak yang akan diperiksa. Nilai harta Wajib Pajak menunjukkan fiscal importance masing-masing Wajib Pajak.
\end{abstract}

Kata Kunci : Perpajakan, Pemeriksaan Pajak, Data Pajak, Harta

\section{PENDAHULUAN}

Pemeriksaan pajak hamper selalu menghadirkan kontroversi dengan timbulnya sengketa pajak (Bwoga, 2019). Namun demikian, pemeriksaan pajak juga bergana untuk menguji kepatuhan wajib pajak (Gunarso, 2016; Harmawati \& Yadnyana, 2016; Prayatni \& Jati, 2016; Sucandra \& Supadmi, 2016; Ezer \& Ghozali, 2017; Assa et al., 2018; RW et al., 2018; Arifin \& Syafii, 2019) yang nantinya juga dapat meningkatkan penerimaan pajak (Fadhillah \& Andi, 2016; Sutrisno et al, 2016; Maulida \& Adnan, 2017; Sunarto \& Muhammad, 2018; Monica \& Andi, 2019; Aprilianto \& Hidayat, 2020). Gunadi dalam diskusi pemeriksaan pajak di Surabaya tahun 2015, mengungkapkan bahwa sumbangan penerimaan dari pemeriksaan masih kecil sehingga diperlukan penambahan audit coverage (www.pajak.go.id). Audit coverage ratio tahun 2015 baru 0,34\%. Gunadi mengusulkan audit coverage dinaikkan menjadi 1-5\%. Langkah-langkah strategis pemeriksaan yang perlu dilakukan menurut Gunadi ada tiga. Pertama, pemanfaatan sistem pemeriksaan dan database yang harus dibangun. Kedua, jumlah dari SP2 yang diterbitkan harus ditingkatkan. Ketiga, saat ini distribusi SDM untuk pemeriksa 14,6\% sedangkan standar OECD 30,4\% sehingga perlu ada penambahan fungsional pemeriksa untuk melakukan pemeriksaan. 


\section{EDUCORETAX}

Volume 1 No. 4, Desember 2021

Berdasarkan Laporan Tahunan Direktorat Jenderal Pajak (DJP) terlihat masih ada keterbatasan sumber daya pegawai yang dimiliki, sehingga Direktorat Jenderal Pajak tidak mungkin melakukan pemeriksaan atas semua wajib pajak. Dalam SE.06/PJ/2016, salah satu usaha Direktorat Jenderal Pajak untuk menjadikan kegiatan pemeriksaan sebagai instrumen untuk mendorong pertumbuhan penerimaan pajak yang berkelanjutan adalah dengan meningkatkan kualitas pemilihan wajib pajak yang dilakukan pemeriksaan. Peningkatan kualitas pemilihan wajib pajak ini juga sebagai program revitalisasi proses bisnis pemeriksaan.

Pemeriksaan khusus dilakukan Direktorat Jenderal Pajak didasarkan adanya keterangan lain berupa data konkret dan analisis risiko. Analisis risiko bisa dengan analisis risiko secara manual yang dibuat oleh pegawai Direktorat Pemeriksaan dan Penagihan, rekomendasi Direktur yang berwenang atas hasil pengembangan dan analisis atas Informasi, Data, Laporan dan Pengaduan (IDLP) yang dilakukan oleh Direktur yang berwenang, atau analisis risiko secara komputerisasi, termasuk hasil analisis dari Compliance Risk Management (CRM)

Direktorat Jenderal Pajak menjelaskan bahwa analisis risiko terkomputerisasi nantinya akan mengandalkan analisis risiko dari compliance risk management. Compliance risk management merupakan sistem manajemen risiko terintegrasi Direktorat Jenderal Pajak. Pada tahun 2015, compliance risk management baru meliputi Pengawasan dan Pemeriksaan. Pada praktek pemilihan wajib pajak yang akan diperiksa, analisis risiko terkomputerisasi masih digunakan dan analisis risiko dari compliance risk management masih dalam tahap piloting pada beberapa kantor pelayanan pajak. Pada piloting analisis risiko compliance risk management., dalam pemilihan wajib pajak yang akan diperiksa, tahun 2015, Direktorat Jenderal Pajak menggunakan 27 variabel yang dibagi dalam sumbu Y untuk fiscal importance dan sumbu X untuk level of compliance. Salah satu variabel yang digunakan dalam sumbu Y adalah variabel nilai harta sebagai salah pertimbangan dalam analisis risiko.

Di sisi lain, dalam lampiran surat S-367/PJ.04/2016, informasi yang ditampilkan pada analisis risiko terkomputerisasi adalah industri, nama, Nomor Pokok Wajib Pajak, alamat, KLU, tahun buku, peredaran usaha, gross profit margin, net profit margin, corporate tax to turnover ratio, dan keterangan. Didalamnya tidak digunakan variabel nilai harta Wajib Pajak. Potensi sumber informasi harta Wajib Pajak sangat banyak. Selain dari data Surat Pemberitahuan, Direktorat Jenderal Pajak mempunyai sumber data lain yang bisa digunakan untuk kepentingannya. Peraturan Pemerintah Nomor 31 tahun 2012, memberikan akses kepada Direktorat Jenderal pajak untuk meminta informasi yang berkaitan dengan perpajakan kepada instansi pemerintah, lembaga, asosiasi dan pihak lain. Salah satu jenis informasi tersebut adalah data yang berkaitan dengan kekayaan atau harta yang dimiliki orang pribadi atau badan. Penelitian ini membahas penggunaan informasi harta pada pemilihan wajib pajak yang akan diperiksa dalam pemeriksaan khusus dengan analisis risiko terkomputerisasi.

\section{KAJIAN PUSTAKA \\ Pemeriksaan pajak}

Pengertian pemeriksaan di bidang perpajakan menurut Mardiasmo $(2000,36)$ adalah serangkaian kegiatan untuk mencari, mengumpulkan dan mengolah data dan atau keterangan lainnya dalam rangka pengawasan kepatuhan pemenuhan kewajiban perpajakan berdasarkan ketentuan peraturan perundang-undangan pajak. Menurut Priantara $(2000,24)$, pemeriksaan merupakan interaksi antara pemeriksa dengan Wajib Pajak. Untuk itu, dibutuhkan sikap positif dari Wajib Pajak sehingga pelaksanaan pemeriksaan dapat lebih efektif.

Berdasarkan Undang-Undang Nomor 6 Tahun 1983 Tentang Ketentuan Umum Dan Tata Cara Perpajakan, sebagaimana diubah terakhir dengan Undang-Undang Republik Indonesia Nomor 16 Tahun 2009: Pemeriksaan adalah serangkaian kegiatan menghimpun dan 


\section{EDUCORETAX}

Volume 1 No. 4, Desember 2021

mengolah data, keterangan, dan/atau bukti yang dilaksanakan secara objektif dan profesional berdasarkan suatu standar pemeriksaan untuk menguji kepatuhan pemenuhan kewajiban perpajakan dan/atau untuk tujuan lain dalam rangka melaksanakan ketentuan peraturan perundang-undangan perpajakan.

Berdasarkan Surat Edaran Direktur Jenderal Pajak Nomor SE-06/PJ/2016, terdapat dua kriteria pemeriksaan yaitu pemeriksaan rutin dan pemeriksaan khusus. Pemeriksaan rutin merupakan pemeriksaan yang dilakukan sehubungan dengan pemenuhan hak dan pelaksanaan kewajiban perpajakan tanpa memerlukan analisis risiko kepatuhan wajib pajak. Pemeriksaan Khusus meliputi: (1) Pemeriksaan khusus berdasarkan keterangan lain berupa data konkret. Pemeriksaan ini merupakan pemeriksaan yang dilakukan terhadap Wajib Pajak yang berdasarkan keterangan lain berupa data konkret menunjukkan adanya indikasi ketidakpatuhan pemenuhan kewajiban perpajakan; (2) Pemeriksaan khusus berdasarkan analisis risiko. Pemeriksaan ini merupakan pemeriksaan yang dilakukan terhadap Wajib Pajak yang berdasarkan hasil analisis risiko menunjukkan adanya indikasi ketidakpatuhan pemenuhan kewajiban perpajakan.

Kebijakan pemeriksaan khusus berdasarkan analisis risiko adalah sebagai berikut: (1) pemeriksaan khusus berdasarkan analisis risiko dilakukan melalui mekanisme bottom up dan top down secara terukur; (2) parameter terukur dalam hal ini adalah Wajib Pajak yang akan dilakukan pemeriksaan harus memenuhi unsur-unsur: memiliki potensi pajak yang dapat diidentifikasi, penanggung pajak diketahui keberadaanya, dan masih memiliki kegiatan usaha aktif; (3) identifikasi potensi pajak didukung dengan data dan/atau informasi yang bersifat kuantitatif dan/atau kualitatif, antara lain alat keterangan, bukti pemotongan/pemungutan $\mathrm{PPh}$, data Pajak Keluaran dan Pajak Masukan, devisa hasil ekspor, kepemilikan harta, hasil visit pegawai yang menjalankan tugas dan fungsi pengawasan terhadap Wajib Pajak dan hasil pengamatan.

Instruksi pelaksanaan pemeriksaan khusus top down yang dibuat oleh Direktur Pemeriksaan dan Penagihan diterbitkan berdasarkan: (1) Analisis risiko secara manual dari usulan kepala subdirektorat di lingkungan Direktorat Pemeriksaan dan Penagihan atau instruksi Direktur Pemeriksaan dan Penagihan; (2) Hasil analisis dan pengembangan atas IDLP yang dilakukan oleh direktur yang berwenang; (3) Analisis risiko secara terkomputerisasi, termasuk hasil analisis dari CRM (compliance risk management.).

\section{Pemilihan Wajib Pajak yang akan diperiksa}

Murphy $(1959,232)$ dalam Wardana $(2015,2)$ menyatakan bahwa untuk memastikan semua Wajib Pajak melaporkan kewajiban pajaknya secara benar adalah dengan melakukan pemeriksaan untuk seluruh Surat Pemberitahuan (SPT). Namun demikian, cara tersebut adalah mustahil sekaligus tidak ekonomis mengingat terbatasnya sumber daya yang dimiliki.

Sejak tahun 1999 secara resmi Direktorat Jenderal Pajak menggunakan teknik sampling audit dalam pemeriksaan pajak, sesuai SE-06/PJ.7/1999 tentang Perlakuan dan Pendekatan Pemeriksaan terhadap Golongan Wajib Pajak serta Penerapan Teknik Sampling dalam Pemeriksaan Pajak. Tujuan utama teknik pemilihan objek pemeriksaan ini adalah sebagai sarana untuk membantu pemeriksa pajak dalam pelaksanaan pemeriksaan pajak agar lebih efisien dan efektif. Direktur Jenderal Pajak juga menyatakan dalam SE-06/PJ/2016 bahwa pemeriksaan khusus dilakukan kepada wajib pajak berdasarkan adanya data konkret dan berdasarkan analisis risiko yang mengindikasikan ketidakpatuhan pemenuhan kewajiban perpajakan.

Menurut Arens et al. (2016), pemilihan sampel audit adalah: “... when the auditor decides to select less than 100\% of the population for testing for the purpose of making inferences about the population, it is called audit sampling". Sedangkan menurut SAS No. 39: "Audit sampling is the application of an audit procedure to less then 100\% of the items within 


\section{EDUCORETAX}

Volume 1 No. 4, Desember 2021

an account balance or class of transaction for the purpose of evaluating some characteristic of the balance or class".

Berdasarkan penelitian yang dilakukan OECD (2004), kunci yang dibutuhkan untuk proses pemilihan audit yang efektif, yaitu: (1) ketersediaan data yang akurat, komprehensif dan tepat waktu; (2) ketersediaan pengetahuan dan kemampuan untuk menganalisis dan memprioritaskan data yang ada, dan untuk memfasilitasi feedback yang memperbarui parameter kasus audit dan proses manajemen risiko kepatuhan pada level strategi; (3) informasi dari pihak ketiga yang mengkonfirmasi detail surat pemberitahuan; (4) histori kasus sebelumnya; (5) profil sektor bisnis secara umum.

Manfaat audit sampling menurut Basalamah $(2003,5)$ khususnya yang menggunakan metode statistik adalah: (1) penentuan besarnya sampel yang harus diperiksa dan evaluasi hasilnya menjadi lebih objektif karena adanya perincian secara statistik mengenai tingkat kesalahan yang diperkirakan, tingkat kehandalan yang dikehendaki, kesalahan maksimum yang dapat ditolerir, metode pemilihan sampel yang memadai guna mengindari bias (kecenderungan auditor pada suatu hal tertentu), serta adanya sarana terbaik untuk menilai sampel; (2) sampling statistik memungkinkan bagi auditor untuk lebih merinci dan mengendalikan risiko sampling dengan menentukan tingkat ketepatan dan keandalan yang dapat dicapai.

Ketika hendak menerapkan audit sampling, menurut Guy. et al. (1986, 5) perlu melakukan hal-hal berikut : (1) Perencanaan, yaitu ketika merencanakan sebuah audit, auditor harus mempertimbangkan hubungan sampel pada relevansi audit spesifik atau tujuan pengendalian internal dan mempertimbangkan faktor lain yang mempengaruhi ukuran sampel. (2) Seleksi, yaitu pemilihan item-item yang digunakan sebagai sampel diharapkan dapat mewakili populasi. Semua item dalam populasi harus memiliki kesempatan untuk dipilih. (3) Evaluasi, yaitu auditor harus memproyeksikan hasil kesalahan dari sampel yang dipilih.

Lebih lanjut Guy. et al. (1986, 65) merumuskan model analisis kualitatif untuk pemilihan sample audit yaitu: (1) menentukan critical dan noncritical error pada lingkup audit; (2) menentukan sifat dan penyebab tiap critical error, yang dapat berupa disengaja atau tidak disengaja, kecerobohan atau salah memahami instruksi, sering atau jarang, sistematis atau acak, dan kemungkinan efek nilai uang; (3) mengevaluasi efek terburuk dari tiap critical error; (4) menentukan konsistensi critical error dengan evaluasi awal dari pengendalian internal, dan memodifikasi rencana audit yang sesuai; (5) menentukan efek dari penyimpangan pada kepatuhan dan uji substantif; dan (6) menyarankan meningkatkan prosedur kepada klien.

\section{Harta}

Dalam PSAK nomor 16 revisi tahun 2015 disebutkan bahwa aset atau harta merupakan semua kekayaan yang dimiliki oleh seseorang atau perusahaan baik berwujud maupun tak berwujud yang berharga atau bernilai yang akan mendatangkan manfaat bagi seseorang atau perusahaan tersebut. Manfaat ekonomi masa depan dalam harta adalah potensi dari harta tersebut untuk memberikan sumbangan, baik langsung maupun tidak langsung, arus kas dan setara kas kepada perusahaan.

Kieso, et. al. $(2014,37)$ mendefinisikan harta sebagai a resource controlled by the entity as a result of past events and from wich future economic benefits are expected to flow to the entity. Pengertian ini sejalan dengan pendefinisian harta dalam perpajakan. Dalam UndangUndang nomor 11 tahun 2016 tentang Pengampunan Pajak, harta didefinisikan sebagai akumulasi tambahan kemampuan ekonomis berupa seluruh kekayaan, baik berwujud maupun tidak berwujud, baik bergerak maupun tidak bergerak, baik yang digunakan untuk usaha maupun bukan untuk usaha, yang berada di dalam dan/atau di luar wilayah Negara Kesatuan Republik Indonesia.

Dalam PSAK 01 tentang Penyajian Laporan Keuangan, harta diklasifikasikan menjadi harta lancar dan harta tidak lancar. Klasifikasi harta lancar harus memenuhi syarat sebagai 


\section{EDUCORETAX}

Volume 1 No. 4, Desember 2021

berikut: (1) Mengharapkan akan merealisasikan harta, atau bermaksud untuk menjual atau menggunakannya dalam siklu operasi normal. (2) Memiliki harta untuk tujuan diperdagangkan. (3) Mengharapkan akan merealisasi harta dalam jangka waktu 12 bulan setelah pelaporan. (4) Kas atau setara kas, kecuali harta tersebut dibatasi pertukarannya atau penggunaannya untuk menyelesaikan laibilitas sekurang-kurangnya 12 bulan setelah pelaporan. Selain empat kriteria tersebut, maka harta diklasifikasikan sebagai harta tidak lancar.

Suryadi $(2006,117)$ dalam Hani dan Lubis (2010) menyatakan bahwa ukuran suatu perusahaan dapat dinilai dari nilai total aktivanya. Akan tetapi, Wajib Pajak besar lebih tinggi tingkat kesadaran perpajakan dibandingkan Wajib Pajak kecil Perusahaan dengan total aktiva lebih besar akan cenderung lebih patuh didalam memenuhi kewajiban pajaknya dibandingkan dengan perusahan yang total aktivanya kecil.

\section{METODE}

Penelitian ini menggunakan metode kualitaif. Cresswell $(2014,59)$ menekankan dalam mendefinisikan penelitian kualitatif pada proses penelitian yang mengalir dari asumsi filosofis, menuju lensa penafsiran, kemudian menuju prosedur yang dilibatkan dalam mempelajari isuisu sosial atau manusia. Ciri-ciri umum dalam penelitian kualitatif menurut Cresswell (2014, 62) antara lain dilaksanakan dalam lingkungan alamiah, sumber data dan interaksi berkelanjutan. Sugiyono $(2015,24)$ mengemukakan penggunaan metode kualitatif antara lain ketika masalah penelitian belum jelas, untuk memahami makna di balik data yang tampak, dan untuk memahami interaksi sosial.

Pertanyaan dalam penelitian ini menggunakan mengapa. Pertanyaan mengapa adalah penelitian yang termasuk penelitian eksplanatif. Penelitian ini tidak hanya cukup untuk mengetahui apa dan bagaimana sesuatu peristiwa terjadi tetapi juga untuk mengetahui dan menjelaskan mengapa suatu peristiwa terjadi. Oleh karena itu, penelitian tipe eksplanatif perlu mengidentifikasi berbagai variabel-variabel di luar variabel yang diteliti, yang mungkin dapat diperkirakan memberi penjelasan terhadap masalah yang diteliti (Wulandari 2010, 45)

\section{Sumber Dan Teknik Pengumpulan Data}

Data yang digunakan dalam penelitian ini meliputi data primer dan data sekunder. Untuk mendapatkan data yang diperlukan digunakan wawancara dan Studi Kepustakaan.

\section{Instrumen Penelitian}

Instrumen utama penelitian adalah penulis sendiri. Sugiyono $(2015,223)$ menyatakan bahwa dalam penelitian kualitatif, "the researcher is the key instrumen". Jadi penulis melakukan pengumpulan data, analisis dan membuat kesimpulan. Alat bantu dalam wawancara yang digunakan penulis adalah daftar pertanyaan wawancara yang telah tersusun dan alat perekam untuk merekam tanya-jawab dengan informan.

\section{Teknik Analisis Data}

Cresswell (2014, 264-265) menyebutkan proses analisis dan penyajian data sebagai berikut: (1) Menciptakan dan mengorganisasikan file untuk data. (2) Membaca seluruh teks , membuat catatan pinggir membentuk kode awal. (3) Mendeskripsikan kategori coding terbuka. (4) Memilih satu kategori coding terbuka untuk fenomena sentralnya. (5) Melakukan coding aksial - kondisi kausal, konteks, kondisi pengganggu, strategi konsekuensi. (6) Melakukan coding selektif dan saling menghubungkan kategori untuk mengembangkan cerita atau proposisi. (7) Menyajikan model visual. (8) Menyajikan proposisi.

Sugiyono $(2015,253)$ menyebutkan bahwa kesimpulan dalam penelitian kualitatif adalah merupakan temuan baru yang sebelumnya belum pernah ada. Temuan dapat berupa deskripsi atau gambaran objek yang sebelumnya masih remang-remang sehingga setelah diteliti menjadi jelas, dapat berupa hubungan kausal atau interaktif, hipotesis atau teori.

\section{Pengujian Keabsahan Data}




\section{EDUCORETAX}

Volume 1 No. 4, Desember 2021

Dalam pengujian keabsahan data, metode penelitian kualitatif menggunakan istilah yang berbeda dengan penelitian kuantitatif, yaitu credibility, transferability, dependability, dan confirmability (Sugiyono 2015, 270).

\section{HASIL DAN PEMBAHASAN}

\section{Variabel harta dalam analisis risiko terkomputerisasi}

Surat Direktur Pemeriksaan dan Penagihan yang ditujukan kepada Para Kepala Kantor Pelayanan Pajak, meminta daftar Wajib Pajak Badan potensial (tax gap tinggi) untuk dilakukan pemeriksaan. Feedback dari masing-masing Kepala Kantor Pelayanan Pajak ini yang akan menjadi dasar analisis risiko terkomputerisasi yang dilakukan oleh Direktorat Pemeriksaan dan Penagihan dalam menentukan Wajib Pajak mana saja yang akan diinstruksikan untuk diperiksa dalam pemeriksaan khusus top down.

Kriteria Wajib Pajak yang potensial meliputi tahun pajak 2013 dan 2014, memiliki kepatuhan kewajiban perpajakan yang rendah atau tax gap tinggi, memiliki potensi pajak yang teridentifikasi, diketahui keberadaanya dengan cek lapangan, Wajib Pajak domisili, industri prioritas program nasional dan regional, tidak mengikuti reinventing policy, apabila mengikuti maka harus ada bukti ketidakbenaran pemanfaatan reinventing policy, dan telah melalui pembahasan oleh Kepala Kantor bersama Kepala Seksi Pemeriksaan, Kepala Seksi Pengawasan dan Konsultasi, dan Supervisor. Disamping itu, dalam lampiran tabel yang harus diisi oleh pihak KPP meliputi nomor, industri, NPWP, nama Wajib Pajak, Alamat, KLU, tahun buku, peredaran usaha yang dilaporkan, gross profit margin, net profit margin, corporate tax to turnover ratio (CTTOR), dan keterangan. Di dalam kriteria maupun lampiran tidak disebutkan adanya variabel harta, padahal dalam analisis risiko Complice Risk Management yang telah berlaku sejak tahun 2015 variabel tersebut telah digunakan.

Berdasarkan hasil wawancara yang telah dilakukan dengan beberapa narasumber, alasan yang dikemukakan cukup beragam. Dua narasumber menjelaskan alasan tidak digunakannya variabel harta Wajib Pajak dalam analisis risiko terkomputerisasi karena analisis sudah diyakinkan dengan analisis kualitatif, berupa adanya proses crosscheck lapangan dan pembahasan oleh pihak internal Kantor Pelayanan Pajak. Narasumber menyampaikan bahwa kriteria yang ditampilkan dalam S-367/PJ.04/2016 merupakan parameter awal untuk mendeteksi Wajib Pajak yang berpotensi. Selanjutnya harus dilihat fakta lapangan yang ada, sehingga pihak Kantor Pelayanan Pajak harus melakukan crosscheck lapangan. Oleh karena itu data ini dianggap cukup valid untuk pemilihan Wajib Pajak potensial untuk diperiksa.

Pendapat tersebut senada dengan pernyataan narasumber lainnya yang menyatakan bahwa informasi yang ditampilkan tidak digunakan untuk analisis Wajib Pajak yang sebenarnya. Proses selanjutnya yang harus dilakukan seperti analisis manual, yaitu pembahasan dengan Kepala Kantor, Kepala Seksi Pemeriksaan, Kepala Seksi Pengawasan dan Konsultasi, dan Supervisor. Pembahasan inilah yang paling menentukan pemilihan Wajib Pajak potensial untuk diperiksa.

Variabel kuantitatif yang berupa omzet, Gross Profit Margin, Net Profit Margin dan CTTOR juga memberikan andil dalam pemilihan Wajib Pajak potensial untuk diperiksa. Dua orang narasumber berpendapat bahwa variabel kuantitatif ini sudah dapat menggambarkan tax gap yang dibutuhkan dalam analisis risiko pemilihan Wajib Pajak yang akan diperiksa.

Salah satu narasumber berpendapat bahwa variabel yang paling dapat merepresentasikan tax gap adalah Gross Profit Margin, Net Profit Margin dan CTTOR, sepanjang dihitung secara konsisten, mengikuti aturan/karakteristik jenis usaha dan memiliki tingkat validitas yang tinggi. Lebih lanjut narasumber menambahkan bahwa nilai harta Wajib 


\section{EDUCORETAX}

Volume 1 No. 4, Desember 2021

Pajak tidak digunakan untuk menunjukkan risiko, tetapi digunakan untuk menunjukkan fiscal importance masing-masing Wajib Pajak.

Narasumber lain mengatakan bahwa untuk melihat wajar tidak wajar sudah bisa jika dibandingkan dengan usaha yang sejenis dari CTTOR. Istilah cost driver masing-masing Wajib Pajak harus diketahui oleh pemeriksa untuk bisa menentukan kewajaran omzet maupun biayanya.

Dua narasumber sepakat bahwa penggunaan nilai harta Wajib Pajak hanya untuk menentukan besaran kontribusi fiskal atau fiscal importance. Disisi lain, dalam S367/PJ.04/2016 ini, besaran kontribusi fiskal sudah terwakili oleh variabel omzet Wajib Pajak.

Sementara itu, narasumber lainnya berpendapat bahwa variabel harta biasanya lebih dekat ke Wajib Pajak Orang Pribadi dibandingkan dengan Badan. Hal ini disebabkan karena wajib Pajak Badan telah membuat laporan keuangan dan rugi laba, sedangkan Orang Pribadi tidak membuat laporan keuangan. Oleh karena itu, satu-satunya cara adalah membandingkan harta tahun lalu dengan harta tahun sekarang dan penghasilannya.

Dari penjabaran tersebut dapat disimpulkan bahwa alasan mengapa nilai harta tidak digunakan dalam penentuan Wajib Pajak potensial untuk diperiksa sesuai S-367/PJ.04/2016 adalah kriteria yang ada sudah cukup dengan data kuantitatif berupa omzet, Gross Profit Margin, Net Profit Margin, dan CTTOR, ditambah pertimbangan kualitatif dengan crosscheck lokasi dan pembahasan di internal Kantor Pelayanan Pajak. Sementara nilai harta hanya menunjukkan fiscal importance.

\section{Variabel harta dalam analisis risiko Compliance Risk Management}

Penggunaan informasi nilai harta dalam analisis Compliance Risk Management pada piloting tahun 2015 ada di dua sumbu. Pada sumbu Y, nilai harta digunakan untuk mendeteksi fiscal importance untuk Wajib Pajak Badan maupun Orang Pribadi. Sedangkan pada sumbu X, informasi harta digunakan untuk mendeteksi apakah Wajib Pajak Orang pribadi tidak melaporkan seluruh penghasilannya.

Hasil wawancara yang telah dilakukan dengan beberapa narasumber untuk menanyakan alasan penggunaan informasi harta ini mendapatkan jawaban yang beragam, namun dapat dikelompokkan dalam tiga pendapat utama sebagai barikut: (a) Nilai harta mencerminkan kemampuan ekonomi Wajib Pajak, sebanyak 2 narasumber. (b) Nilai harta sebagai indikator fiscal importance Wajib Pajak, sebanyak 2 narasumber. (c) Nilai harta sebagai indikator adanya penghasilan yang didapat dari pemanfaatan harta tersebut, sebanyak 4 narasumber.

Gambar 2. Alasan penggunaan variabel harta dalam CRM
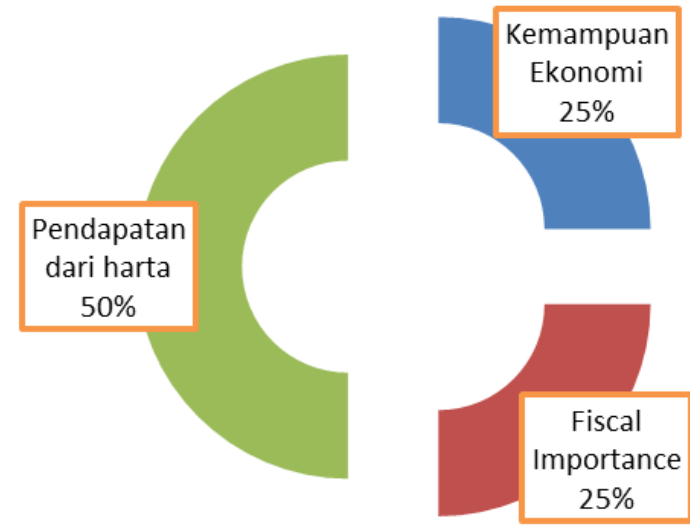

Sumber: Diolah dari hasil wawancara

Narasumber menyebutkan bahwa informasi harta dapat mencerminkan indikasi awal kemampuan ekonomi Wajib Pajak. Untuk melihat kalau itu merupakan objek pajak atau tidak, maka harus dilakukan pengecekan lagi. Dapat diasumsikan bahwa bila nilai harta besar 


\section{EDUCORETAX}

Volume 1 No. 4, Desember 2021

seharusnya penghasilannya juga besar. Selain itu, penggunaan informasi harta ini dapat digunakan untuk mengejar Wajib Pajak yang tidak mengikuti program Tax Amnesty. Wajib Pajak yang tidak mengikuti Tax Amnesty akan menjadi prioritas, karena adanya batas waktu tiga tahun sejak berlakunya program Tax Amnesty untuk membuktikan adanya kepemilikan harta Wajib Pajak yang tidak mengikutinya.

Senada dengan pendapat diatas, dalam hal pasca pemeriksaan, yaitu fungsi harta berperan dalam tahap penagihan, narasumber lain berpendapat bahwa nilai harta yang besar menandakan kemampuan yang besar untuk membayar ketetapan pajak dari hasil pemeriksaan. Dengan adanya informasi harta, tidak akan menyulitkan dalam proses penagihan.

Sementara itu, narasumber lainnya sepakat bahwa penggunaan nilai harta dalam Compliance Risk Management adalah sebagai petunjuk fiscal importance Wajib Pajak. Nara sumber ada yang berpendapat bahwa "Variabel harta ini akan sangat membantu membedakan Wajib Pajak yang satu dengan yang lain. Sepanjang faktor-faktor risiko sudah mampu menangkap ketidakpatuhan WP, variabel harta di sumbu Y dan kombinasi dengan variabelvariabel lain penyusun sumbu Y, akan sangat membantu baik penetapatan pemilihan Wajib Pajak untuk diperiksa, maupun sesudah diperiksa dalam hal penagihan ketetapan jika pemeriksaan menetapkan ketetapan pajak dengan nilai yang besar."

Narasumber juga ada yang mengatakan bahwa nilai harta berada pada sumbu Y yang menandakan Wajib Pajak ini mempunyai konsekuensi fiskal yang lebih. Misalnya ada Wajib Pajak dengan aset Rp 1 miliar dibandingkan dengan Wajib Pajak yang asetnya Rp100 juta, maka kita akan memilih yang asetnya Rp1 miliar. Nilai harta ini akan menentukan kuadran diatas atau dibawah dalam sumbu Y.

Dari hasil wawancara, empat narasumber sepakat bahwa nilai harta menunjukkan kemungkinan adanya penghasilan yang diperoleh dari harta tersebut. Narasumber lain menjelaskan bahwa "Dia punya apartemen, rumah lebih dari 1, itu kan potensi untuk mendapatkan penghasillan sewa. Apabila di SPT-nya tidak ada penghasilan dari rumah itu, maka perlu kita curigai ngapain dia beli tapi tidak dimanfaatkan. Kemudian yang kedua apabila ada uang tunai, tambahan uang tunai sekian juta rupiah. Uang itu ditaruh dimana? Kalau memang uang itu ditaruh di rumah, oke fine. Akan tetapi, kalau misalnya uang itu dalam bentuk tunai, otomatis dia akan diputar dan tidak mungkin cuma ditaruh disitu saja. Jadi hartanya semua itu pasti akan kita lihat bukan hanya harta bergerak tetapi harta yg tidak bergerak kita lihat juga. Tapi yg paling penting memang harta yg tidak bergerak yg menghasilkan income."

Narasumber lain berpendapat bahwa setelah didapat informasi harta dari program Tax Amnesty, nilai harta ini di bandingkan dengan penghasilan yang diperoleh. Apabila nilai harta dan penghasilan tidak sebanding, maka Wajib Pajak perlu diminta untuk menjelaskan perbedaan ini. Ketidakseimbangan ini dapat mengindikasikan adanya penghasilan yang disembunyikan. Hal ini dicontohkan narasumber lain misalnya ada harta dalam bentuk persediaan dapat mengindikasikan penghasilan. Perputaran persediaan dalam satu periode bisa mencerminkan omzet yang didapat.

Sementara itu, narasumber juga ada yang menjelaskan dengan logika Persamaan akuntansi, dari satu sisi nambah maka sisi lain harus ada yg nambah. Harta berada di sisi debet dalam neraca, sehingga apabila ada pertambahan harta, berarti harus ada pertambahan di sisi kredit, bisa dari penghasilan atau utang.

Dilihat dari kebutuhan beragam variabel narasumber ada yang berpendapat sebagai berikut bahwa "Semakin banyak variable yang masuk dalam formulasi maka error akan lebih kecil, dan item-nya lebih pas. Nah kalau memasukan variabel kan ada alasanya kalau dalam ilmu modelling, kalau secara teori berpengaruh maka dalam formula kita masukin. Yang kita harapkan apa? Kita harapkan untuk kita menempatkan risiko, ini resiko kecil atau besar nih. Dari hasil formula ini maka harta menjadi salah satu variabel yang layak secara konsep." 


\section{EDUCORETAX}

Volume 1 No. 4, Desember 2021

Dari beberapa pendapat diatas dapat disimpulkan bahwa alasan penggunaan informasi harta dalam analisis Compliance Risk Management adalah untuk menjadi variabel fiscal importance, sehingga diketahui kemampuan membayar Wajib Pajak atas ketetapan pajak hasil pemeriksaan, dan menjadi indikator adanya penghasilan dari pemanfaatan harta tersebut. Kriteria-kriteria yang digunakan dalam Compliance Risk Management lebih dominan kriteria kuantitatif, sehingga semakin banyak kriteria, maka semakin tepat analisis yang dilakukan.

Dibandingkan analisis risiko terkomputerisasi, Compliance Risk Management membutuhkan lebih banyak tenaga, karena harus memasukkan data dalam tabel dengan format microsoft excel. Dalam Compliance Risk Management, data yang dikumpulkan kantor pusat diturunkan ke dalam risk engine. Perbedaan karakteristik inilah yang menjadi alasan perbedaan kriteria pemilihan yang digunakan, Compliance Risk Management membutuhkan data yang lebih kompleks.

\section{PENUTUP}

Dalam analisis terkomputerisasi, Direktorat Jenderal Pajak sejak tahun 2015 menggunakan dua metode, yaitu analisis risiko terkomputerisasi (pada tahun 2016 dengan Surat S-367/PJ.04/2016) dan analisis Compliance Risk Management. Salah satu pembeda diantara keduanya adalah dalam penggunaan variabel nilai harta Wajib Pajak.

Alasan mengapa nilai harta tidak digunakan dalam penentuan Wajib Pajak potensial untuk diperiksa sesuai S-367/PJ.04/2016 adalah karena sudah cukup data kuantitatif yang digunakan dalam pemilihan wajib pajak yang akan di periksa seperti data omzet, Gross Profit Margin, Net Profit Margin, dan CTTOR, ditambah pertimbangan kualitatif dengan crosscheck lokasi dan pembahasan di internal Kantor Pelayanan Pajak.

Alasan penggunaan informasi harta dalam analisis Compliance Risk Management adalah untuk menjadi variabel fiscal importance, sehingga diketahui kemampuan membayar Wajib Pajak atas ketetapan pajak hasil pemeriksaan, dan menjadi indikator adanya penghasilan dari pemanfaatan harta tersebut. Kriteria-kriteria yang digunakan dalam Compliance Risk Management lebih dominan kriteria kuantitatif, sehingga semakin banyak kriteria, maka semakin tepat analisis yang dilakukan.

Penyebab utama perbedaan penggunaan variabel antara analisis risiko terkomputerisasi dan analisis Compliance Risk Management anatar lain analisis terkomputerisasi membutuhkan lebih banyak tenaga, karena harus memasukkan data dalam tabel dengan format microsoft excel. Sedangkan dalam compliance risk management., data yang dikumpulkan kantor pusat diturunkan ke dalam risk engine.

\section{Keterbatasan}

Belum dilakukan kajian secara komprehensif terkait penggunaan informasi harta dalam pemilihan wajib pajak yang akan diperiksa dalam pemeriksaan khusus. Penelitian ini tidak menggunakan data rinci informasi harta Wajib Pajak yang dilaporkan maupun informasi dari pihak ketiga. Program compliance risk management.masih dalam tahap piloting pada tahun 2015 dan terhenti pada tahun 2016 karena program Tax Amnesty.

\section{DAFTAR PUSTAKA}

Aprilianto, B., \& Hidayat, A. (2020). Pengaruh Bisnis E-Commerce dan Pemeriksaan Pajak terhadap Penerimaan Pajak (Studi Kasus Wajib Pajak Yang Terdaftar di KPP Kelapa Gading). EkoPreneur, 1(2), 156-168.

Arens, A. A., Elder, R. J., Beasley, M. S., \& Hogan, C. E. (2016). Auditing and assurance services. Auditing and Assurance Services. 


\section{EDUCORETAX}

Volume 1 No. 4, Desember 2021

Arifin, S. B., \& Syafii, I. (2019). Penerapan E-Filing, E-Billing Dan Pemeriksaan Pajak Terhadap Kepatuhan Wajib Pajak Orang Pribadi Di Kpp Pratama Medan Polonia. Jurnal Akuntansi Dan Bisnis: Jurnal Program Studi Akuntansi, 5(1), 9-21.

Assa, J. R., Kalangi, L., \& Pontoh, W. (2018). Pengaruh Pemeriksaan Pajak Dan Sanksi Perpajakan Terhadap Kepatuhan Wajib Pajak Pada Kantor Pelayanan Pajak Pratama Manado. Going Concern: Jurnal Riset Akuntansi, 13(04).

Bwoga, H. (2019). Pemeriksaan Pajak Yang (hampir selalu) menimbulkan kontroversi. Jurnal Informasi, Perpajakan, Akuntansi, Dan Keuangan Publik, 1(2), 135-144.

Ezer, E., \& Ghozali, I. (2017). Pengaruh Tingkat Pendapatan, Tarif Pajak, Denda Pajak, dan Probabilitas Pemeriksaan Pajak Terhadap Kepatuhan Pajak. Diponegoro Journal of Accounting, 6(3), 407-419.

Fadhillah, M. R., \& Andi, A. (2016). Kesadaran Wajib Pajak, Kegiatan Sosialisasi Perpajakan, Pemeriksaan Pajak dan Penagihan Pajak terhadap Penerimaan Pajak Penghasilan Badan Pada Kantor Pelayanan Pajak Pratama Tigaraksa. Jurnal Riset Akuntansi Terpadu, 9(1).

Gunarso, P. (2016). Pemeriksaan pajak dan sanksi pajak terhadap kepatuhan wajib pajak badan pada KPP Kepanjen Kabupaten Malang. Jurnal Keuangan dan Perbankan, 20(2), 214223.

Harmawati, N. K. A., \& Yadnyana, I. K. (2016). Pengaruh pemahaman perpajakan, kualitas pelayanan, ketegasan sanksi pajak dan pemeriksaan pajak pada kepatuhan wajib pajak PBB-P2 dengan tingkat pendidikan sebagai pemoderasi (Studi empiris pada dinas pendapatan Kabupaten Jembrana). E-Jurnal Ekonomi dan Bisnis Universitas Udayana, 5(6), 1513-1542.

Maulida, C. I., \& Adnan, A. (2017). Pengaruh Self Assessment System, Pemeriksaan Pajak, Dan Penagihan Pajak Terhadap Penerimaan Pajak Pertambahan Nilai (PPN) Pada KPP Pratama Banda Aceh. Jurnal Ilmiah Mahasiswa Ekonomi Akuntansi, 2(4), 67-74.

MAPPI. (2018). Kode Etik Penilaian Indonesia dan Standar Penilaian Indonesia Edisi VII. Jakarta: MAPPI.

Monica, R., \& Andi, A. (2019). Pengaruh Kepatuhan Wajib Pajak, Pemeriksaan Pajak, Dan Pencairan Tunggakan Pajak Terhadap Penerimaan Pajak Badan Pada Kantor Pelayanan Pajak Pratama Serang Tahun 2012-2016. Jurnal Riset Akuntansi Terpadu, 12(1).

Prayatni, P. T. D., \& Jati, I. K. (2016). Pengaruh kondisi keuangan perusahaan, pemeriksaan pajak dan sikap wajib pajak terhadap kepatuhan wajib pajak hotel. E-Jurnal Akuntansi, 17(1), 663-689.

RW, N. S., Bagianto, A., \& Yuniati, Y. (2018). Pengaruh Pemeriksaan Pajak terhadap Kepatuhan Wajib Pajak dan Dampaknya terhadap Efektivitas Penerimaan Pajak Penghasilan Badan. Jurnal Ilmiah MEA (Manajemen, Ekonomi, \& Akuntansi), 2(2), 115-143.

Sucandra, L. K. I. P., \& Supadmi, N. L. (2016). Pengaruh kualitas pelayanan, pemeriksaan pajak, pengetahuan perpajakan dan sanksi perpajakan pada kepatuhan wajib pajak restoran. E-Jurnal Akuntansi Universitas Udayana, 16(2), 1210-1237.

Sunarto, S., \& Muhammad, A. (2018). Pengaruh Pemeriksaan Pajak, Penagihan Pajak, Dan Kepatuhan Wajib Pajak Terhadap Penerimaan Pajak Studi Kasus Pada Kpp Pratama Raba Bima Tahun 2012-2015. Akuntansi Dewantara, 2(1), 37-45.

Sutrisno, B., Arifati, R., \& Andini, R. (2016). Pengaruh Kewajiban Kepemilikan NPWP, Pemeriksaan Pajak, Penagihan Pajak, Surat Paksa Pajak Dan Kesadaran Wajib Pajak Terhadap Penerimaan Pajak (Pada Kantor Pelayanan Pajak Pratama di Kota Semarang). Journal Of Accounting, 2(2). 